\title{
ANALISIS VISUAL GAMBAR ANAK PADA MASA PRA-SKEMATIK
}

\author{
Oleh : \\ I Wayan Nuriarta ${ }^{1}$, Ida Ayu Dwita Krisna Ari' ${ }^{2}$, G Gde Suryawan ${ }^{3}$ \\ ${ }^{1,2}$ Jurusan Desain Komunikasi Visual, Fakultas Seni Rupa dan Desain, Institut Seni \\ Indonesia Denpasar, Indonesia, ${ }^{3}$ UHN I Gusti Bagus Sugriwa Denpasar \\ email: nuriarta@isi-dps.ac.id, krisnaaridwita@gmail.com, suryaseni87@gmail.com
}

Diterima 6 September 2021, direvisi 20 September 2021, diterbitkan 1 Oktober 2021

\begin{abstract}
Abstrak
Tulisan ini dibuat untuk membaca tanda visual dan tanda verbal yang terdapat pada gambar anak pada masa pra-skematik. Pembacaan terhadap tanda tersebut akan digunakan untuk mendeskripsikan unsur-unsur seni rupa pada gambar anak. Penelitian ini menggunakan rancangan penelitian deskriptif dengan metode kualitatif. Jenis data dalam penelitian ini adalah data kualitatif berupa teks visual dan teks verbal gambar anak. Metode dan teknik pengumpulan data dalam penelitian ini adalah teknik dokumentasi dan studi kepustakaan. Data dianalisis dengan tahapan mengumpulkan data, mengklasifikasikan data, menganalisis berdasarkan teori yang dirumuskan, dan menarik kesimpulan. Dari sejumlah karya anak yang diobservasi, empat karya anak TK dengan masing-masing berjudul "Mama", "Kakak", "Kebun Binatang" dan "Pohon" dipilih sebagai Subjek kajian. Keempat karya tersebut dipilih karena keempat karya tersebut dibuat dengan menggunakan media yang berbeda yaitu menggunakan media pensil pada kertas, cat air pada kertas dan media digital. Objek penelitian ini difokuskan pada analisis visual gambar anak yang melingkupi titik, garis, bidang, ruang dan warna serta cerita yang disampaikan. Tahap pra skematik ditandai dengan munculnya gambar-gambar melingkar dengan garis-garis yang seolah-olah menunjukkan sosok manusia atau hewan. Selama tahap ini skema (ide visual) dikembangkan. Gambar menunjukkan apa yang anak anggap paling penting tentang subjek. Ada pemahaman tentang ruang - objek ditempatkan secara sembarangan di seluruh gambar. Penggunaan warna lebih emosional daripada logis. Bentuk-bentuk dalam gambar yang dihasilkan dari unsur rupanya adalah; 1) Garis secara keseluruhan sudah terkontrol sehingga telah membentuk objek-objek yang diinginkan. 2) Bentuk objek atau bidang yang digambarkan secara keseluruhan sudah teridentifikasi mewakili objek yang ingin digambarkan anak. 3) Warna yang digunakan dalam penggambaran bentuk objek yang digambarkan secara keseluruhan berdasarkan imajinasi anak dan keinginan anak, kecuali penggambaran bentuk pohon menunjukan warna-warna seperti di alam, daun berwarna hijau, langit berwarna biru, dan rumput bewarna hijau. Secara umum gambar yang dihadirkan oleh anak adalah gambar ilustrasi.
\end{abstract}

Kata Kunci: Gambar Anak, Analisis Visual, Masa Pra-skematik.

\section{Abstract}

This article aims to read visual signs and verbal signs by utilizing the children's drawings during the pre-schematic stage. The reading of the signs will be used to describe the elements of fine arts in the children's drawing. This study uses a 
descriptive design with qualitative methods. The type of data in this study is qualitative data in the visual and verbal text. Data collection methods and techniques in this research are documentation techniques and literature study. The data was analyzed and carried out with the stages of identifying and describing data, classifying data, analyzing based on the formulated theory, and drawing conclusions. Four works of kindergarten children were chosen and observed. The four works are entitled "Mother", "Brother", "Zoo" and "Tree". These have been selected as the subjects of the study. These four works were chosen because these works were created by using different media, such as pencil on paper, watercolors on paper, and digital media. The object of this study is focused on visual analysis of the children's drawings on the elements of art, such as points, lines, shape, spaces, and colors. The pre-schematic stage is characterized by the appearance of circular images with lines that seem to indicate human or animal figures. During this stage, the scheme (the visual idea) is developed. The drawing shows what the child considers most important about the subject. There is a little understanding of space objects are placed randomly throughout the image. The use of color is more emotional than logical. The elements of fine art are shown in the drawings can be described as the result of the observation 1) The lines have been controlled so has formed the image. 2) The shape of the object described has been identified as representing the object that the child wants to describe. 3) The colors used to fill the shapes are based on the child's imagination and desires except the color used to fill the shape of the tree. The colors of nature are the same as in real life, such as green leaves, blue sky, and green grass. In general, the image or drawing presented by the child is an illustration.

Keywords: Child's drawing, Visual Analysis, Pre-schematic Stage

\section{PENDAHULUAN}

Masa anak-anak adalah masa yang sangat menyenangkan untuk membuat gambar apa saja. Dalam dunia anak-anak menggambar merupakan sarana pengekspresian gagasan, ide dan berbagai pengalaman yang telah dialaminya. Aktivitas menggambar memiliki peranan yang sangat penting, mengingat pembendaharaan kosa kata anak masih sangat terbatas. Gambar menjadi sesuatu yang paling utama dilihat sebelum memahami kata-kata atau kalimat. Anak-anak melihat dan mengenal sesuatu sebelum mereka berbicara. Anak-anak mengungkapkan ide-ide yang dilihatnya kemudian mengungkapkan dengan goresangoresan sebelum mereka mengungkapkan dengan kata-kata. Hal ini yang dimaksud dengan proses menyampaikan ide secara visual. Gambar yang dibuat oleh anak dapat dikatakan sebagai gambar ilustrasi. Gambar ilustrasi adalah gambar yang menceritakan atau menerangkan sesuatu.

Menggambar merupakan suatu proses berkomunikasi secara visual bagi anak-anak. Sebagai salah satu media komunikasi, gambar juga dapat menjadi media ekspresi untuk mengungkapkan perasaan, suasa hati dan keinginan. Anak-anak dapat menggambar bebas sesuka hatinya baik itu hasil pengalaman mereka atau menggambar beraneka macam bentuk representasi atas pemikiran terhadap sebuah objek. Aktivitas menggambar dapat menyalurkan cara pandang anak dan konsep-konsep sederhana yang 
dimilikinya. Gambar sebagai bahasa kedua merupakan cara anak dalam menyampaikan pesan dan berkomunikasi. Gambar ini disebut juga sebagai karya komunikasi visual. Sebagai salah satu cara berkomunikasi, dan media bekspresi untuk mengungkapkan perasaan, suasa hati dan keinginan yang ingin disampaikan oleh anak, maka kita harus mengerti dan memahami apa yang dikomunikasikan tersebut.

Tahap perkembangan artistik gambar anak terdiri dari: 1 . Coretan (2 sampai 4 tahun) Tahap Coretan terdiri dari empat sub-tahap. (a) Tidak teratur - tanda yang tidak terkendali yang bisa tebal atau ringan tergantung pada kepribadian anak. Pada usia ini anak memiliki sedikit atau tidak ada kontrol atas aktivitas motorik.

Longitudinal - pengulangan gerakan yang terkontrol. Menunjukkan secara visual kesadaran dan kenikmatan gerakan kinestetik. (c) Melingkar eksplorasi lebih lanjut dari gerakan terkontrol yang menunjukkan kemampuan untuk melakukan bentuk yang lebih kompleks. (d) Penamaan anak itu bercerita tentang coretan. Ada perubahan dari berpikir kinestetik dalam hal gerak menjadi berpikir imajinatif dalam hal gambar. Ini adalah pengembangan kemampuan untuk memvisualisasikan imajinasi dalam gambar.

2. Pra Skematik (4 sampai 7 tahun). Tahap pra skematik ditandai dengan munculnya gambar-gambar melingkar dengan garis-garis yang seolah-olah menunjukkan sosok manusia atau hewan. Selama tahap ini skema (ide visual) dikembangkan. Gambar menunjukkan apa yang anak anggap paling penting tentang subjek. Ada sedikit pemahaman tentang ruang objek ditempatkan secara sembarangan di seluruh gambar.
Penggunaan warna lebih emosional daripada logis.

3. Skema (7 sampai 9 tahun) Tahap ini mudah dikenali dengan menunjukkan kesadaran konsep ruang. Objek dalam gambar memiliki hubungan dengan apa yang naik dan apa yang turun. Sebuah dasar yang pasti dan garis langit terlihat jelas. Item dalam gambar semuanya terkait secara spasial. Warna direfleksikan saat muncul di alam. Bentuk dan objek mudah ditentukan. Melebih-lebihkan antara figur (manusia lebih tinggi dari rumah, bunga lebih besar dari manusia, anggota keluarga besar dan kecil) sering digunakan untuk mengungkapkan perasaan yang kuat tentang subjek. Teknik lain yang kadang-kadang digunakan disebut "melipat" ini ditunjukkan ketika objek ditarik tegak lurus dengan garis dasar. Terkadang objek tampak digambar terbalik. Fenomena lain disebut "Xray". Dalam gambar $\mathrm{X}$-ray subjek digambarkan terlihat dari dalam maupun luar.

Gambar anak memiliki kecenderungan menampilkan gambar berdasarkan pengalaman yang pernah dilihatnya dan dialaminya. Objek dalam gambar anak biasanya menampilkan benda-benda langit seperti, matahari, bulan, bintang, awan, pelangi, dan sebagainya. Bendabenda di darat seperti, manusia, bangunan, pohon, kendaraan, dan sebagainya. Kemudian benda-benda yang ada di air seperti ikan dan sebagainya. Maka dari itu peneliti mencoba akan menguraikan objek yang digambar anak dari benda-benda di alam sekitarnya yang coba diinterpretasikan anak melalui gambarnya. Pada penelitian ini, gambar anak pada masa pra-skematik akan menggunakan subjek penelitian gambar Ida Ayu Yoni Nilawati 
Sutapahala yang selanjutnya disebut Yoni pada penelitian ini. Gambar Yoni dipilih karena menunjukan tanda gambar pra-skematik dalam berbagai media gambar. Media gambar ada yang menggunakan kertas gambar dan pensil, kertas gambar dan warna serta menggambar menggunakan digital. Ketiga contoh dipandang memiliki keterwakilan media untuk anak dalam membuat gambar. Objek penelitian akan membahas objek-objek yang dibuat pada media gambar, titik, garis, bidang, ruang, warna dan cerita yang dibangun atau dikomunikasikan melalui gambar.

\section{METODE}

Penelitian ini menggunakan rancangan deskriptif dengan metode kualitatif. Jenis data dalam penelitian ini adalah data kualitatif berupa teks visual dan teks verbal yang terdapat pada gambar anak. Metode dan teknik pengumpulan data dalam penelitian ini adalah teknik dokumentasi dan studi pustaka. Analisis data dilakukan dengan tahapan mengidentifikasi dan mendeskripsikan data, mengklasifikasikan data, melakukan analisis berdasarkan teori yang telah ditentukan, serta menarik simpulan.

\section{PEMBAHASAN}

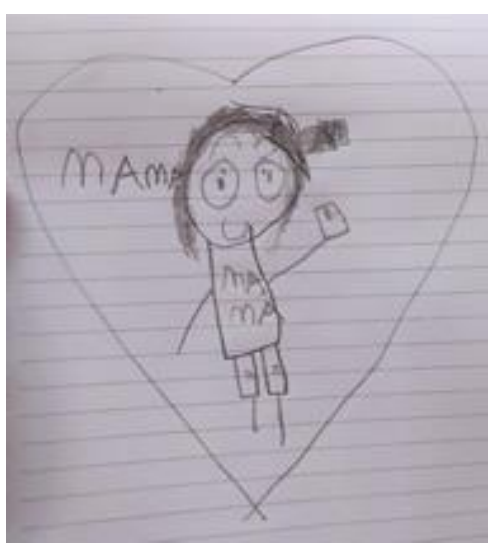

Gambar 1A. "Mama" karya Ida Ayu Yoni Nilawati Sutapahala karya 2021

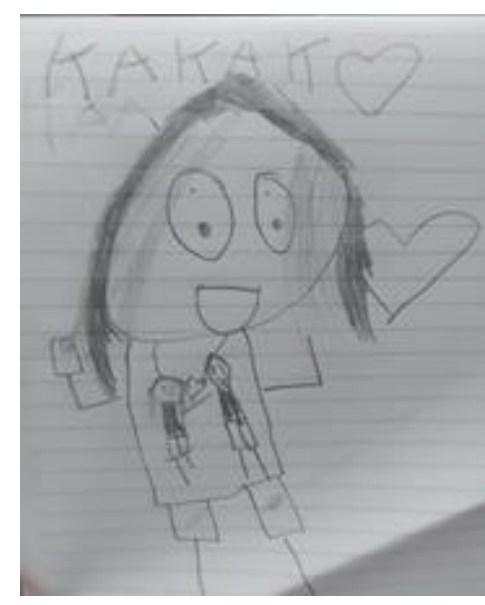

Gambar 1B. "Kakak" karya Ida Ayu Yoni Nilawati Sutapahala karya 2021

Gambar 1A karya Yoni berjudul "Mama" dan karya 1B berjudul "Kakak". Dua gambar ini dibuat menggunakan media pensil pada kertas. Dengan memanfaatkan unsur seni rupa dan desain berupa garis, Yoni telah membuat sebuah gambar dengan representasi yang ada dalam pikirannya. Jelas yang digambarnya adalah Ibu dan kakaknya. Gambar tidak saja dibuat berupa visual, namun juga dipertegas dengan memanfaatkan tulisan yang berisi kata Mama pada gambar 1A, dan kata Kakak pada gambar 1B. Kedua gambar ini juga memiliki ciri yang serupa dengan adanya tanda love.

Kedua gambar tersebut memiliki ciri yang serupa. Ciri-ciri tersebut dapat kita lihat serupa dengan memperhatikan bahwa; (a) Gambar dalam bidang kertas hanya menghadirkan satu tokoh utama, sehingga fokus gambar sangat jelas adalah ilustrasi manusia. (b) kedua gambar diisi keterangan vebal dengan tulisan satu kata yaitu Mama pada gambar 1A, dan Kakak pada gambar 1B. (c) Kedua gambar ditampilkan dengan menghadirkan bentuk jantung yang biasa dibaca sebagai cinta atau kasih sayang atau love. Gambar 1A 
goresan yang berupa jantung dibuat dengan ukuran besar, sehingga gambar seorang mama ada dalam jantung besar tersebut. Pada gambar 1B, kehadiran gambar jantung ditampilkan secara visual dengan ukuran yang lebih kecil. Namun gambar jantung dibuat dengan jumlah lebih banyak dari gambar 1A, yaitu dihadirkan gambar dua jantung pada dekat visualisasi kakak. Jika diperhatikan lebih mendalam, pada gambar 1B dalam dada atau badan tokoh digambarkan kembali dua tokoh manusia yang saling menatap. Gambar diatas dibuat dengan memanfaatkan garis lengkung atau membentuk lingkaran kecil yang diisi titik untuk menggambarkan mata, lingkaran yang lebih besar untuk menggambarkan kepala. Pakaian yang berupa baju dan celana dibuat dengan cara memanfaatkan bidang persegi panjang. Tangan dan kaki manusia hanya dibuat dengan memanfaatkan satu garis. Masing-masing figur manusia, baik yang diberi sebutan Mama ataupun gambar dengan tulisan Kakak memegang benda persegi empat dengan ukuran kecil di tangannya. Bentuk rambut dibuat dengan memberikan coretan secara menumpuk hingga gambar terlihat hitam sebagai ciri warna rambut. Dua gambar ini hanya memanfaatkan unsur seni rupa dan desain berupa titik dan garis. Unsur yang lain seperti warna dan tekstur tidak tampak pada gambar. Gambar yang dibuat menunjukkan apa yang Yoni anggap paling penting tentang subjek.

Yoni saat membuat gambar selalu bercerita tentang gambar yang ia buat. Tangannya yang sambil memainkan pensil diatas kertas, diiringi dengan berbagai cerita yang ingin dia sampaikan. Pada gambar 1A, yoni menceritkan tentang dirinya yang melihat Mama-nya sebagai seorang ibu yang menyayanginya. Ia berkata seperti mengingat-ingat sesuatu sambil berkomunikasi dengan mengatakan;"...ini mama, matanya, rambutnya. Kadang rambut mama diikat. Mama sering ngajak yoni foto seperti ini (sesuai gambar). Mama aku isiin love ya ma?". Caranya bercerita tentang gambar yang ia buat.

Mirip seperti membuat gambar Mama, ia pun melakukan hal yang serupa dengan gambar untuk Kakak-nya. Teman bermain yang paling sering diajak di rumah adalah kakaknya. Kakaknya sebagai orang terdekat selain Mamanya pun menjadi bagian ide, gagasan untuk membangun imajinasi gambarnya. Gambar yang dibuat menjadi karya komunikasi visual untuk menyampaikan berbagai pesan kecintaannya pada keluarga, pada kakaknya. "Ini kakak Lingga yang sering main HP (Handphone)". Sambil terus menceritakan tentang kakaknya di rumah, ia terus membuat gambar. Kedua gambar isi berisi cerita tentang kedekatan Yoni dengan mama dan kakaknya. Gambar ini bercerita tentang orang-orang dekat yang menyayanginya.

Pada tahapan pembuatan gambar ini dapat dilihat adanya metode pembuatan gambar pada anak. Metode yang berbeda dari hanya corat coret telah dimulai, kesadaran berkreasi telah terbentuk. Tahapan ini telah berkembang secara langsung setelah corat-coret. Meskipun gambar tersebut mungkin tidak terlihat berbeda di hadapan orang dewasa. Bagi anakanak perkembangan tahapan ini menjadi sangatlah penting. Pada tahap ini kesadaran dalam membuat bentuk yang memiliki hubungan dengan dunia disekelilingnya telah digambarkan oleh Yoni. Kesadaran dalam membuat bentuk ini adalah tahapan yang 
memiliki arti penting, pembaca gambar diajak harus menyadari bahwa ini adalah awal dari komunikasi visual untuk menyampaikan pesan. Tanda dan coretan ini makin hilang dari hubungannya dengan gerak tubuh sembarang anak-anak, dan tanda ini sudah mulai terkontrol dengan subjek visualnya, memiliki kemiripan bentuk.

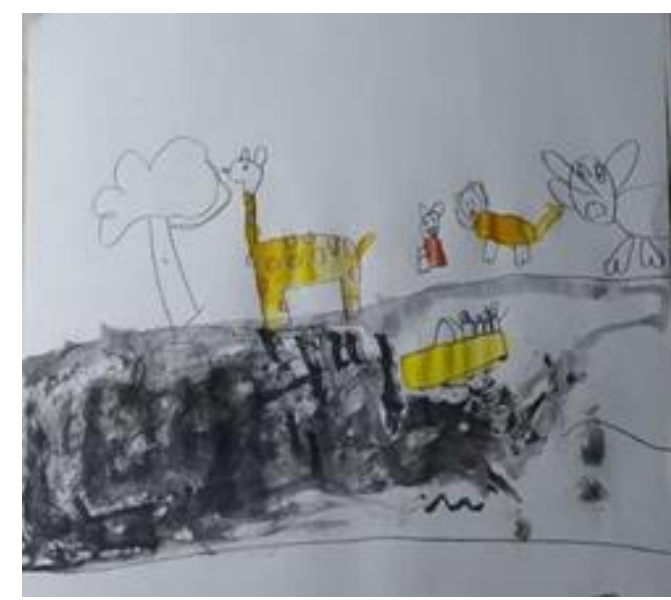

Gambar 2. "Kebun Binatang" karya Ida Ayu Yoni Nilawati Sutapahala tahun 2021.

Gambar 2 berjudul "Kebun Binatang". Gambar ini dibuat dengan memanfaatkan media pensil dan cat air pada kertas. Gambar ini terdiri dari subjek penggambaran secara visual berupa gambar pohon, binatang, manusia dan kendaraan. Secara keseluruhan pada bidang gambar diperlihatkan suasana lingkungannya.

Tahap pembuatan gambar ini menunjukan bahwa Yoni menggambar menggunakan pensil. Setelah gambar terwujud dengan pensil, selanjutnya cat air dimanfaatkan untuk menghadirkan warna. Pada gambar secara visual menggambarkan susana keluarga yang sedang berada di kebun binatang. Hal ini terlihat dari objekobjek yang digambarkan menunjukan adanya pohon besar, binatang berleher panjang, binatang kecil dengan posisi duduk, binatang dengan rambut lebat pada bagian leher dan binatang dengan belalainya. Jika dilihat ciri-cirinya maka secara berurutan setelah gambar pohon dari kiri ke kanan dapat dibaca binatang yang digambarkan adalah jerapah, kelinci, Singa dan Gajah.

Pada bagian bawah gambar secara visual tampak satu keluarga yang sedang naik mobil. Keluarga tersebut tampak karena dalam mobil hadir secara visual gambar manusia. Penggambaran manusia dengan ukuran yang lebih besar diantara gambar manusia yang lain berada di pinggir mobil dan manusia dengan ukuran kecil pada posisi di tengah. Gambar ini memberikan ciri aktivitas keluarga ke kebun binatang sebagai proses imanjinasi Yoni untuk menghadirkan kembali segala sesuatu yang ia lewati.

Dalam penggambarannya dapat dilihat bahwa subjek pohon dan binatang dibuat dengan ukuran yang lebih besar daripada gambar manusia pada mobil. Secara komunikasi visual, karya ini menyampaikan bahwa fokus utama penggambaran adalah binatang karena situasi secara umum memang kebun binatang. Keluarga yang sedang berkunjung adalah bagian yang mendapatkan fokus pengamatan setelah binatang dalam gagasan gambar.

Dengan memanfatkan warna kuning, merah, oranye dan hitam suasana keceriaan dihadirkan juga dengan menunjukan ekspresi keluarga yang berkunjung. Unsur seni rupa dan desain yang digunakan dalam gambar ini adalah garis melengkung dan garis lurus, serta warna yang dimanfaatkan menggunakan cat air. Garis melengkung berbentuk lingkaran atau setengah lingkaran digunakan untuk menggambar daun pada pohon secara umum. Garis ini juga digunakan untuk 
menggambar mata, bentuk kepala binatang dan kepala manusia. Selanjutnya bentuk persegi panjang digunakan untuk membuat bagian batang pohon, badan binatang dan badan manusia. Teknik pewarnaan menggunakan cara memasang warna dengan sangat acak seperti memperlakukan pensil pada warna hitam. Goresan sapuan kuas dengan warna hitam masih meninggalkan jejak-jejaknya. Berbeda dengan warna merah, oranye dan kuning yang dihadirkan dengan memanfaatkan kuas lebih basah, sehingga sapuan kuas tidak tampak. Pada warna-warna ini, tiap subjek gambar diwarnai dengan lebih hati-hati, sangat tampak dari cara memposisikan warna pada subjek. Fokus warna pada subjek gambar juga dipahami sebagai bentuk ide Yoni untuk menghadirkan objek utama pengamatan pada pembaca.

Gambar yang dihadirkan adalah gambar ilustrasi yang menceritakan kembali pengalaman yang telah dilalui Yoni. Dalam gambar tetap menghadirkan anggota keluarga sebagai makna bahwa Yoni sebagai anak sangat mencintai keluarganya. Menceritakan kembali pengalaman bermain ke kebun binatang melalui gambar adalah cara penyampaian pesan kepada siapa saja yang melihat gambar tersebut.

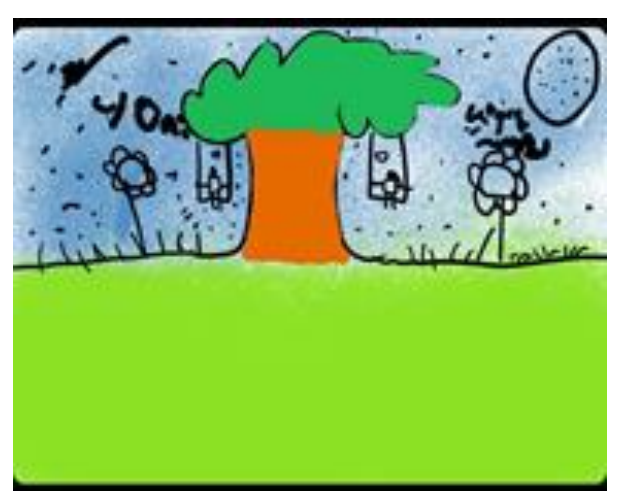

Gambar 3 "Pohon" karya Ida Ayu Yoni Nilawati Sutapahala tahun 2021
Gambar 3 adalah karya Yoni dengan judul "Pohon" yang dibuat pada media digital menggunakan iPad dengan program Procreate. Yoni tidak saja menjelajah media kertas, namun juga mencoba media digital. Keinginannya dalam menggambar di dukung oleh Ibunya. Menjelajah dunia digital menjadi hal yang berbeda buat Yoni. Dengan berbagai fitur-fitur pada program Procreate, Yoni mencoba menggunakannya secara bebas, namun tetap membuat gambar dengan caranya tersendiri yaitu bercerita dan menggores.

Dengan memanfaatkan media digital, secara visual warna dan garis tampak lebih merata dan halus. Warna-warna dihadirkan dengan berbagai cara, seperti cara blok pada warna hijau kekuningan, jingga dan hujau kebiruan. Sementara warna biru dihasilkan dengan memanfaatkan brush. Pemanfaatan warna dengan cara berbeda juga menghadirkan karakter visual yang bervariasi. Line yang digunakan sebagai kontur gambar memanfaatkan warna hitam.

Kombinasi warna dan garis ini menghadirkan gambar berupa pohon besar di lapangan luas. Dengan rumput yang hijau, tampak sebelah kiri dan kanan pohon terdapat gambar bunga. Lingkaran paling pojok kanan atas adalah simbol matahari sebagai tanda hari. Berbagai titik-titik disebarkan secara acak, namun jika diperhatikan titik-titik ini seperti menunjukan adanya tanda hembusan angin di tanah lapang yang luas tersebut. Angin adalah sesuatu yang tidak bisa dilihat secara kasat mata, dan mustahil itu digambarkan. Tetapi bagi Yoni, angin kemudian mampu dihadirkan sebagai sesuatu yang ada dengan memanfaatkan titik-titik yang bergerak karena adanya angin. Dampak gerak titi-titik dimanfaatkan sebagai tanda 
adanya angin segar lingkungan tempat tinggalnya.

Pohon besar yang menjadi centre of interest gambar dihadirkan pada bagian tengah bidang gambar. Pada pohon dibuat ada gambar dua orang sedang bermain ayunan. Orang yang digambarkan sangat kecil sehingga gambar pohon menjadi sangat besar. Sesuai dengan cerita yang disampaikan Yoni saat menggambar, dua orang yang dihadirkan adalah sosok dirinya (diperjelas dengan tulisan Yoni pada gambar) dan mamanya yang sering mengajaknya bermain di rumah maupun ke luar rumah. Pada gambar ke tiga ini juga, Yoni selalu menghadirkan keluarga dalam karyanya.

Jika diamati lingkungan tempat tinggal Yoni, maka pembaca gambar akan menyaksikan bahwa pohon besar sebagai tempatnya bermain memang benar adanya di depan rumahnya. Diantara pohon besar itulah Yoni bersama keluarga dan teman-temannya bermain. Pohon ini hadir diantara sawah-sawah yang membentang, sehingga suasana segar angin yang berhembus bisa dirasakan oleh siapa saja yang berada di sana. Yoni menggambarkan kembali berbagai hal yang ia lewati ke dalam media gambar. Kehidupan sehari-hari adalah bekal dan imaniasinya untuk menghadirkan gambar ilustrasi ini.

Dalam pembuatan gambar di usia 4 tahun, Yoni lebih ikut serta dengan aktifitas kinetiknya, tetapi sekarang setelah berumur 6 tahun dia sudah ikut serta dalam pengembangan dan hubungannya dengan apa yang sebenarnya dia ingin tampilkan. Hal ini memberikan Yoni kepuasan yang sangat besar dalam menggambar. Ditambah Yoni mampu memanfaatkan berbagai media untuk membuat gambar. Gambar-gambar yang dihasilkan ini sangatlah penting bagi anak, orang tua dan guru yang memiliki peran yang sangat erat dengan proses perekaman pemikiran anak-anak. Hal ini tidak saja memberikan orang dewasa sebuah gambar atau objek nyata yang mereka bisa lihat dan diskusikan dengan anak, tetapi juga memberikan kode tentang apa hal yang penting dalam kehidupan anak tersebut dan bagaimana dia memulai dan mengorganisir hubungannya dengan lingkungan.

Pada umur 6 tahun, tandanya atau bentuk sudah mulai dapat dibaca oleh orang-orang seperti gambar rumah, pohon dan orang. Setiap anak memiliki banyak variasi dalam bentuk. Dan material yang mereka gunakan sangat mempengaruhi tampilan visual gambar yang mereka buat. Beberapa faktor juga mempengaruhi jenis gambaran yang dibuat sesuai dengan tangkapan momen yang menjadi pusat perhatiannya. Keluarga, kegiatan keseharian dan tempat tinggal menjadi salah satu sumber ide yang digunakan oleh Yoni dan anak-anak pada umumnya dalam membuat gambar. Segala sesuatu yang sangat dekat baginya adalah ide pertama yang akan muncul sebagai cerita dalam gambar. Gambar pada masa pra skematik mulai meghadirkan bentuk yang terkontrol dengan subjek karya lingkungan.

\section{SIMPULAN}

Bentuk-bentuk dalam gambar Yoni pada masa pra skematik ini jika dilihat dari unsur rupanya adalah sebagai berikut: 1) Garis secara keseluruhan sudah terkontrol sehingga telah membentuk objek-objek yang diinginkan. Garis yang teridentifikasi adalah garis lurus pada pengambaran pakaian, batang pohon, kendaraan. Sedangkan garis melengkung pada penggambaran pada mata, kepala 
manusia maupun binatang dan gambar bunga. Garis tersebut disusun sesuai berdasarkan kemampuan anak menjadi bentuk objek yang ingin digambarkan dalam bentuk yang sederhana dan berdasarkan kemampuan gerak otot jari anak (fisiologi). 2) Bentuk objek atau bidang yang digambarkan secara kesuluruhan sudah teridentifikasi mewakili objek yang ingin digambarkan anak. Bentuk atau bidang yang teridentifikasi meliputi bidang organik dan geometris, diantaranya bidang atau bentuk organik pada penggambaran hampir keseluruhan objek yang digambarkan kecuali pada penggambaran objek mobil, karena objek mobil terdidiri dari susunan bidang geometris seperti segiempat. Bentuk objek yang digambarkan berdasarkan pada pemahaman anak mengenai bentuk dan kemampuannya dalam memvisualkan bentuk yang digambarkan. Bentuk masih dalam tahap sederhana, seperti bentuk manusia masih dalam tahap manusia batang dengan sudah menunjukan bentuk yang bervariatif dengan berbagai ekspresi. 3) Warna yang digunakan dalam penggambaran bentuk objek yang digambarkan secara keseluruhan berdasarkan imajinasi anak dan keinginan anak, kecuali penggambaran bentuk pohon menunjukan warna-warna seperti di alam, daun berwarna hijau, langit berwarna biru, dan rumput bewarna hijau. Penggunaan warna sebagian besar berdasarkan dari imajinasi anak dan keinginan anak pada saat menggambar. Gambar Yoni menunjukan suasana bermain di kebun binatang, terlihat dari beberapa bentuk objek yang digambarkan memiliki ciri-ciri objek yang berada di kebun binatang seperti, digambarkannya berbagai binatang, pepohonan tempat hewan itu dipelihara serta objek manusia yang menunjukan ekspresi gembira berkunjung ke kebun binatang. Berdasarkan karakteristik gambarnya, pada gambar Yoni memiliki tipe susunan bebas. Hal ini dapat dilihat pada gambar Yoni bahwa objek-objek ditampilkan belum mempunyai urutan cerita secara khusus.

\section{DAFTAR PUSTAKA}

Arsini, N. W., Ketut, N., Kusuma, S., Sutriyanti, N. K., Hindu, U., Gusti, N. I., Sugriwa, B., Kumara, K. J., Gianyar,

K., Jambe, T. K., Kabupaten, K., Pendidikan, N., Hindu, K., \& Dini, A. U. (2020). INTERNALISASI NILAI PENDIDIKAN KARAKTER HINDU. 5(2), 95-111.

Darmaprawira, W.A, Sulasmi. 2002. Warna: Teori dan Kreativitas, Penggunaannya. Bandung: Penerbit ITB.

Depdiknas Dirjen Dikti. 2005. Pengembangan Kreativitas Senirupa Anak TK. Jakarta.

Kurniati, A., Kudus, I., Marwah, M., \& Hartati, H. (2020). Pembelajaran Kearifan Lokal Pakaian Adat Suku Buton bagi Anak Usia Dini. Jurnal Obsesi : Jurnal Pendidikan Anak Usia Dini, 5(2), 1101-1112. https://doi.org/10.31004/obsesi.v5 i2. 737

Marianto, M Dwi. 2015. Art \& Levitation, Seni dalam Cakrawala Quantum. Yograkarta : Pohon Cahaya.

Nuriarta, I. W. (2019). Tanda Dan Makna Kartun Politik Koran Jawa Pos Tahun 2019. Mudra Jurnal Seni Budaya, 34(3), 366-371. https://doi.org/10.31091/mudra.v3 $4 \mathrm{i} 3.795$ 
https://ejournal.ihdn.ac.id/index.p hp/PW/article/view/1796/1715 http://rahmisyahputri99.blogspot.co.id /2014/12/mengembangkan-kreativitasanak-usia.html 